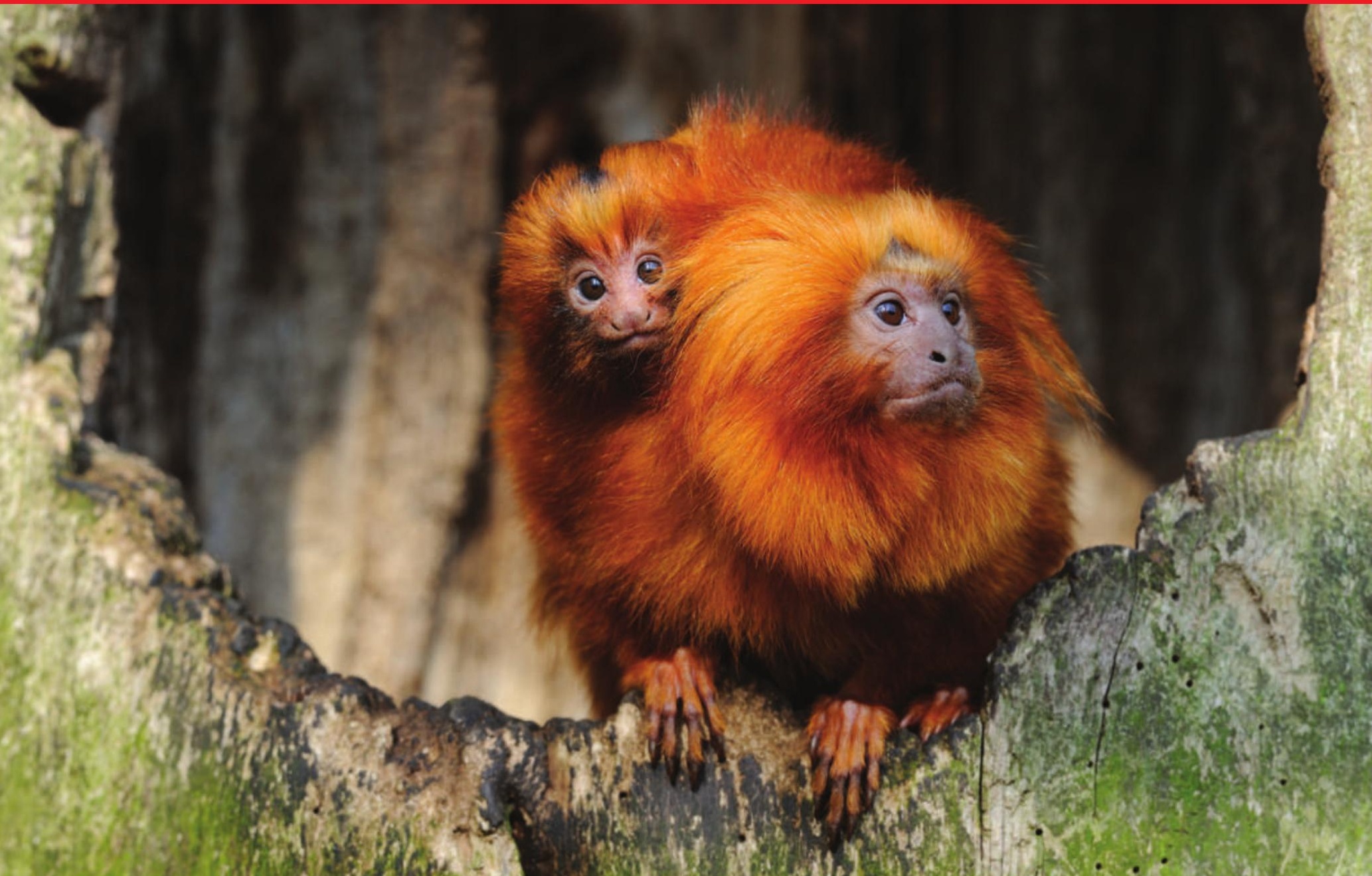

\title{
Biodiversity's bright spot
}

\section{While species losses mount worldwide, conservationists in Brazil have made great strides towards saving the golden lion tamarin and its forest habitat from destruction. Gene Russo reports.}

1 $\mathrm{t}$ a farm less than two hours from the sprawl of Rio de Janeiro, a small group of ecotourists strolls to a patch of forest to see one of the rare victories in the fight to preserve Earth's dwindling biodiversity. Walking among trees near the town of Silva Jardim, the visitors are greeted with high-pitched squeals emanating from the canopy. A few seconds later, they spot tufts of brilliant orange fur flying from branch to branch as three families of golden lion tamarin (Leontopithecus rosalia) compete for territory in an area that should really accommodate only one.

The overcrowding of these small, twitchy primates in this forest fragment demonstrates both the successes and remaining challenges surrounding efforts to preserve the golden lion tamarin and its native habitat, the Atlantic forest of Brazil. Known as Mata Atlântica, these scattered fragments of forest dot the eastern coast of Brazil and contain one of the richest assortments of endemic species in the world, many of them endangered. And like the golden lion tamarin, the Atlantic forest almost disappeared because of development and an exploding human population. But both the flagship primate and its habitat have been saved, at least temporarily.

"When I come to the Atlantic forest, I think 'Thank

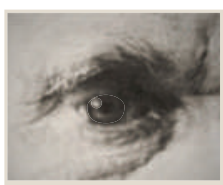

Biodiversity

God," says Russ Mittermeier, president of Conservation International. Mittermeier, who travels the world visiting places in various states of ecological distress, lauds the area's conservationists, researchers and a frequently supportive public. "It's as good as it gets," he says.

By many measures, that's still not very good. The scraps of Atlantic forest occupy only about $10 \%$ of the area covered when Europeans arrived in 1500 (see map, opposite). And just $9 \%$ of those remaining bits are protected.

But the rate of deforestation has slowed in the past decade and in some places conservation efforts have even helped the forest to rebound. Beyond the hectares saved, the resurgence of the Atlantic forest shows how successful conservation can emerge through a combination of forces. The lessons learned here may resonate beyond Brazil, as nations seek to reverse the rapid loss of the planet's species. "The Atlantic forest shows that it's not a hopeless cause in these high-priority areas," says Mittermeier.

For this biome, it was the plight of the golden lion tamarin that helped motivate a conservation movement. As its habitat vanished, the population of these primates dropped to roughly 150 individuals in the 1970s, which caused conservationists and researchers to take aggressive action to save the species (see 'Bred to survive', overleaf). But it soon 
became clear that the golden lion tamarin could not be preserved on its own.

Jim Dietz, a conservation biologist at the University of Maryland in College Park, remembers flying over the Atlantic forest in a helicopter in 1985 while there to investigate the tamarins. He was stunned by what he saw - a speckled landscape of forest fragments interspersed among pastures. The sight turned Dietz from a golden lion tamarin researcher to a forest conservationist. "I was down there to study mating systems," he says. "But I hadn't understood the grave nature of the threat."

Stemming the deforestation required a broad set of measures: new laws and governmental incentives, the commitment of researchers and conservationists, increased funding from international donors and the Brazilian government, and a growing community awareness. Lately, a boost has come from efforts to emphasize the forest's value as a source of water, a draw for ecotourism and a generator of other ecosystem services.

International pressure has also helped. Through the Convention on Biological Diversity, countries have committed to slow the rate of biodiversity loss and to protect $10 \%$ of their ecoregions by 2010. Although few nations will meet these goals, Brazil has set aside $16 \%$ of its land. Most of this is in the Amazon, but the biodiversity treaty has put pressure on Brazilian authorities to establish state parks in the Atlantic forest southwest of São Paulo, says Oliver Hillel, an officer in the convention's secretariat in Montreal, Canada.

\section{In the balance}

Preservation efforts have to fight against a long history of forest destruction in the Mata Atlântica. Shortly after landing in the region in 1500, Portuguese settlers began cutting down trees. By 1797, they had cleared so much land that Queen Maria the Pious of Portugal called for measures to stop the forest's destruction. In recent decades, sugarcane cultivation, logging and ranching have shattered the forest into fragments. Oil exploration on the coast and massive development - 70\% of Brazil's 200 million people live within the Atlantic forest biome - have shrunk it further.

Estimates vary of how much forest survives. Measurements that count only fragments larger than 100 hectares indicate that just $7-8 \%$ of the forest is left. Calculations that include smaller fragments and more mountainous areas suggest that $11-16 \%$ remains. In either case, the forest is badly broken up. Roughly $83 \%$ of the fragments are less than 50 hectares in size (M. C. Ribeiro et al. Biol. Conserv. 142, 1141-1153; 2009). The smaller the fragment, the harder it is to sustain existing ecosystems, especially those that include animals with large ranges, such as tamarin, jaguar, puma and many birds.

And yet, despite the devastation, these splintered ecosystems remain a hotbed of life. The forest, which stretches from the eastern tip of Uruguay northeast through Brazil's population centres to the tiny state of Rio Grande Do Norte, contains a far more varied range of elevations and climates than the vast Amazon basin. Its diverse environments support an unusually high number of species, many of them existing only in this biome. The Atlantic forest has an estimated 20,000 plant species, 8,000 of which are believed to be endemic. And 940 of its 2,155 vertebrate species are thought

\section{"When I come to the Atlantic forest, I think 'Thank God'.} It's as good as it gets." - Russ Mittermeier to be endemic. Roughly 190 animal species and 300 plants in the forest are considered threatened. Based on this density of life alone, there is a lot at stake.

The Brazilian government took a significant step to preserve its forests in 1965, when it revised the country's forest code. The law required landowners to preserve areas around rivers and forests on steep slopes. For the Atlantic forest, it dictated that $20 \%$ of any rural property must be maintained as a reserve.

More legislation in the 1980s and 1990s sought to conserve forest resources and ecosystems. But it was not until 2006 that Brazil passed a law specifically to protect the Atlantic forest, by demarcating its extent and its ecosystems and by requiring special permission for activities that damage them. The law prohibits the removal of vegetation in areas housing endangered species. It also provides for watershed protection, erosion control and the formation of corridors between forest remnants.

The long struggle to win even the promise of such safeguards was led in part by Marina Silva, a senator who had previously served as environment minister. She and others had battled an array of forces including the timber industry and landowners. Despite the environmental victories in the legislature, it has been difficult to win protection on the ground. "If the forestry code had been enforced and complied with, we would probably have $30 \%$ of the Atlantic forest left," says Lucio Bede, manager of Conservation International's Atlantic forest programme. Although the code specified punishment, it provided no real incentives for compliance. And enforcement has been lax, says Bede.

\section{THE FRACTURED FOREST}

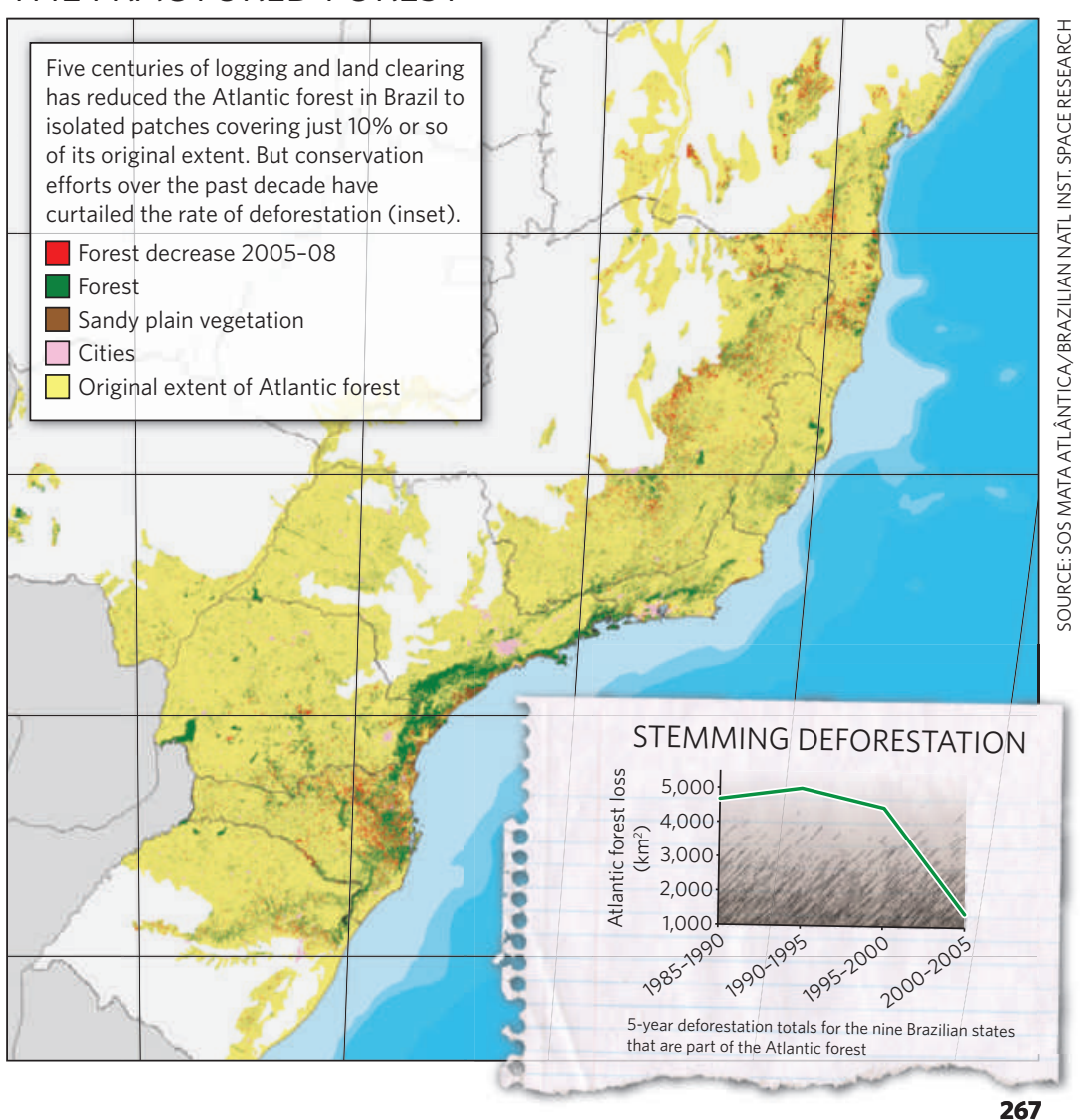


As for the Atlantic Forest Law, Silva says that too few municipalities are engaged in monitoring and recovery efforts. "The application of the law is not uniform throughout all Atlantic forest states," she says. The state of Santa Catarina, for example, has attempted to loosen the federal law with its own environmental code. But even with such problems, the recent law has helped raise awareness and slow deforestation, says Silva.

Notions of pristine environments, peaceful forest canopies and noble animals hold scant interest for poor people seeking jobs and income. So conservationists have recently tried a different tactic, stressing what intact forests can do for people living everywhere from rural towns to the megacities of São Paulo and Rio de Janeiro. These population centres rely on the forests to provide clean water, and deforestation threatens the watershed serving millions.

This approach relies on advertising the ecosystem services provided by the forest, a tactic adopted by conservation proponents and researchers in many parts of the world over the past decade. In Brazil, it is starting to yield results. "Municipalities are just beginning to understand conservation and environmental services," says Denise Marçal Rambaldi, secretary-general of the Golden Lion Tamarin Association and a key figure in the project to save the species. "Decisions made in a municipality are much more important for land use and planning than those in the federal government."

\section{A river runs through it}

In the city of Petrópolis, 70 kilometres outside of Rio de Janeiro, a small river runs near the summer residence of Pedro II, emperor of Brazil in the nineteenth century. The Piabanha river has become a focus of efforts to preserve the forest in and around the city. In 1992, Petrópolis and its surrounds became the first federally decreed environmental protection area. Now, engineers and local government officials are trying to conserve and enhance the vegetation along the river, in the hope that the Piabanha can serve as a thread that sews together forest fragments on the edges of the city.

The challenges are many. In spots, particularly at high altitudes, forest fires have eliminated native plants and allowed invasive grasses to take hold. Roads, condominium developments and shanty towns known as favelas impinge on the watershed, threatening water quality and encouraging erosion. According to Yara Valverde, a biologist and former head of the Petrópolis protection area, irresponsible development could lead to floods that would taint water sources. But the city imposes fines for environmental crimes. And guided by citizens and federal and local governments, the preservation efforts have allowed landowners to protect former grazing lands, allowing for some natural regeneration of the forest.

The progress, albeit incremental, in Petrópolis demonstrates the potential of emphasizing what the forest provides to the environment and community. "We hope to incorporate conservation planning into watershed planning and create an economy based on ecosystem services," says José Maria Cardoso da Silva, Conservation International's vice-president for South America. Currently, there are legal mechanisms to pay landowners to protect forests along a watershed; the crucial next step is to develop overall governance structures for each watershed across the Atlantic forest, says Cardoso da Silva. Government-sanctioned watershed committees have started to form that include local government, businesses and conservation organizations. By charging for water use, some committees have generated money for conservation, reforestation and sanitation management. The focus on ecosystem services, says Bede, makes clear how protecting the forest helps preserve the water supply.

Valuing ecosystem services, however, does not necessarily protect the forest's flora and fauna, because it shifts the emphasis away from saving species. Mittermeier endorses continued ecosystem-services projects but he warns: "If we

\section{Bred to survive}

Behind the animal enclosures at the Smithsonian National Zoo in Washington DC, Jennifer Mickelberg is greeted by a golden lion tamarin, which swings by and peers through the bars at a photo in her hands. The animal squeals at the glossy picture of a tamarin resting on a branch. "Yeah, that's your papa," coos Mickelberg.

She should know. Mickelberg is the assistant keeper of the 'stud book' - a database tracing the family tree of all 500 golden lion tamarins currently housed at 150 institutions worldwide and 3,500 of their ancestors. With these records and populationmanagement software, the stud-book keeper decides which tamarins to breed together to maintain the captive population's genetic diversity.

The antecedents of this breeding programme began in the early 1960s, following a crash in the Brazilian population of wild golden lion tamarins. At first, scientists struggled to get tamarins to breed in captivity, but by the 1970s they had learned to include more protein in the animals' diet and to base social groups on monogamous pairs.

As captive breeding became more successful, tamarins from these programmes augmented the dwindling wild population in Brazil. At the same time, a network of dozens of zoos, led by the National Zoo, stepped up efforts to track genetic pedigrees,

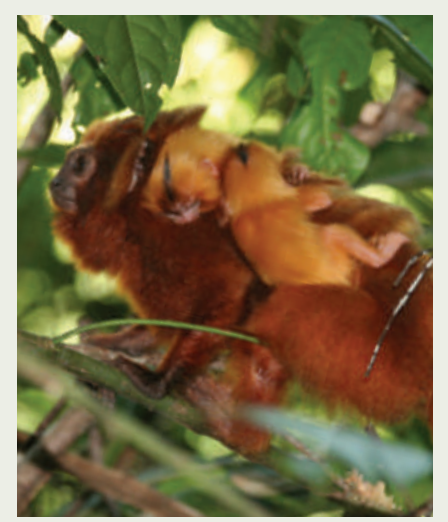

hoping to minimize inbreeding. When researchers are considering a pair of potential mates, they examine mean kinship, the level of relatedness between an individual and a population, and another factor called the inbreeding coefficient, a measure of relatedness to a potential mate. Currently the wild population of golden lion tamarins - found only in Brazil - has grown to the point at which animals raised in captivity are not being released. But the zoo population must remain healthy and genetically robust, in case a massive forest fire or some other catastrophe hits the wild population. As part of their work, researchers must also seek to keep artificial selection from happening in captivity. If the zoo environment were to encourage certain traits over many generations, there could be a propensity to produce animals adapted to captivity but maladapted to the wild. 

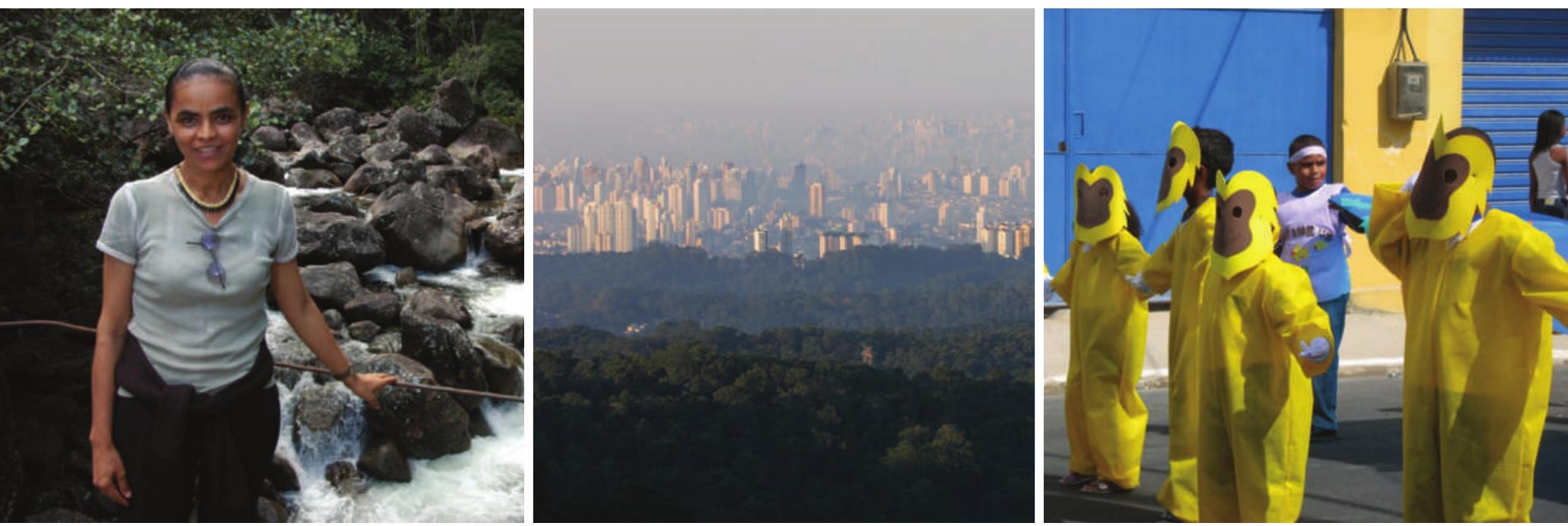

Marina Silva (left) has helped protect the Atlantic forest, which borders cities such as São Paulo (centre). A parade in Silva Jardim shows local support for saving the golden lion tamarin.

focus on the ecosystem-service argument only, and don't focus on critical endangered species, then we could end up with good forest and good ecosystem services but no species."

Although different approaches could sometimes come into conflict, an emphasis on ecosystem services may actually dovetail well with protecting species, according to an unpublished study. Frank Wugt Larsen, a postdoc at Conservation International's Center for Applied Biodiversity Science in Arlington, Virginia, assessed 524 sites around the world in terms of the species they harbour and the services they provide, such as storing carbon in vegetation and providing clean water. He found that areas identified as the last-known habitat for a given species provide more ecosystem services than nearby 'control' areas.

In Brazil, the case of the golden lion tamarin shows how multiple conservation interests can converge to raise public awareness and move landowners to action. For more than 40 years, Marcos da Silva Freire and his family have owned 350 hectares, outside Rio near Poço das Antas, the first federal biological reserve in Brazil. Freire, an immunologist, works in Rio like many middle-class landowners, but he maintains the land and visits when he can. In the late 1980s, researchers contacted him and his father about introducing two groups of tamarins, bred in zoos, onto their land. They agreed, and theirs was the first of several farms to offer the animals indefinite accommodation.

But interspecies altruism is not the only factor that motivates Freire. He enjoys the tamarins - and he has considered establishing his own ecotourism venture to bring in additional revenue.

Other conservation efforts could help sustain poor farmers and, at the same time, enlist them to protect the forest. On a hot, clear day in August, Adeildo Ataliba proudly shows visitors his plot of land near the Poço das Antas reserve, one of the main homes of the golden lion tamarins. Walking through tall trees and shrubs, he points to plants he has recently sown, including seedlings of coffee, yucca, guava and jatoba. Nearby is a large banana tree and a single stalk of sugarcane.

Just a few years ago, this land was a field of ankle-high scrub. As part of an agrarian resettlement effort, Ataliba and his family were one of several landless families who received a plot from the government. But many of these families struggled because they lacked agricultural training and an environment conducive for traditional cash crops. A few of the farmers even resorted to hunting in the nearby reserve. In an effort to aid the farmers and protect the reserve, the Golden Lion Tamarin Association - whose mission has expanded beyond tamarins since it was founded in 1992 - established 'agroforestry systems' of native tree species planted together with vegetables and fruits. This helps restore forest corridors for wild animals and yields produce for the families. The association helps out farmers by providing seedlings and technical assistance.

Conservation groups have even more ambitious aims for the future. A coalition of non-governmental organizations, research institutions and private companies hopes to double the amount of Atlantic forest by 2050. Some of the money for this effort, expected to cost tens of billions of dollars, could come from payments to store forest carbon, an ecosystem service that could become much more valuable under a new climate treaty.

As the various stakeholders in Brazil explore different approaches to preserving the Atlantic forest, the golden lion tamarins continue to multiply in their newfound territory. Currently, their population in the wild has swelled to around 1,500 on more than 10,000 hectares of protected land. But in many places, pastures and roads prevent the growing families from expanding into new territory. Dietz is seeking funding to join up enough isolated tamarin populations via forest corridors to enable gene flow throughout the entire population. "It would be self-sustaining in perpetuity," he says.

Rambaldi warns that the tamarins and their habitat still face significant threats. "We have ten years to ensure the legal protection and the sustainability of these fragments," she says. Otherwise, urban pressures and oil exploration threaten to claim land. And the fragmented forest, says Rambaldi, will become just an empty collection of trees. Gene Russo is editor of Naturejobs.

See Editorial, page 251, and online at www.nature.com/darwin. 